\title{
TEOLOGICZNIE O KRYTYCE KAPITALIZMU: UJĘCIE JOHNA MILBANKA I RUCHU RADYKALNEJ ORTODOKSJI*
}

DOI: http://dx.doi.org/10.12775/TiCz.2020.050

Streszczenie. Krytyka kapitalizmu jest w ostatnich kilkunastu latach coraz częstszym polem zainteresowania teologów. Motyw ten jest także częstym przedmiotem oficjalnego nauczania Kościołów i organizacji ponadwyznaniowych i ekumenicznych. Współczesny kapitalizm jest często ujmowany jako wywołujący zagrożenie dla społeczeństwa i środowiska naturalnego i jednocześnie jako poważna przyczyna sekularyzacji i dechrystianizacji. Celem artykułu jest prezentacja fragmentu refleksji Johna Milbanka, odnoszącego się do krytycznej oceny kapitalizmu i ukazanie jej na tle podsumowania najważniejszych teologicznych punktów programowych szkoły Radykalnej Ortodoksji, teologicznego środowiska, którego Milbank jest liderem. W artykule zostaje przeprowadzony analityczny komentarz wybranych tekstów Milbanka, tak zestawionych, aby w możliwie reprezentatywnym stopniu osiągnąć zamierzone cele.

Słowa kluczowe: Radykalna Ortodoksja; kapitalizm; anglikanizm; ekonomia daru; chrześcijański socjalizm.

* Artykuł został opublikowany w ramach projektu finansowanego przez Narodowe Centrum Nauki, nr 2018/31/B/HS1/01254. 
Abstract. Theologically on the Criticism of Capitalism: the Approach of John Milbank and the Radical Orthodoxy Movement. The critique of capitalism increasingly has attracted much interest from theologians in the last decades. The topic is also the official teaching of both the Churches and ecumenical organizations. Contemporary capitalism is frequently regarded as a threat to societies and environment and, simultaneously, as a serious cause of secularization and dechristianization. The article presents selected concepts of John Milbank's reflection that refers to the criticism of capitalism and shows it in the perspective of a summary of the crucial theological points of the Radical Orthodoxy movement. The text is an analytical commentary on the selected works of Milbank that have been compiled in order to achieve the intended goals.

Keywords: Radical Orthodoxy; capitalism; Anglicanism; economy of gift; Christian socialism.

Na teologicznej mapie nowych kierunków istotne miejsce zajmuje od kilku dekad ruch tzw. Radykalnej Ortodoksji (Radical Orthodoxy, dalej RO). Nazwa może budzić zaskoczenie, idzie bowiem pod prąd intuicji. Zarówno radykalność głównych tez ruchu, jak i ich ortodoksja mają bowiem specyficzne znaczenie odczytywanej na nowo ich inherentności we współczesnych okolicznościach epistemologicznych. Dotyczy więc raczej sfery intelektualnej, a nie moralnej czy związanej ze stylem życia. Szkoła RO jest antyliberalna, ale w znaczeniu odnoszącym się do teologicznego liberalizmu, to jest podkreślania roli indywidualnego doświadczenia religijnego $\mathrm{w}$ poznaniu teologicznym. Jej antyliberalizm zasadza się na ustawicznym podkreślaniu powrotu do Chalcedonu, teologii patrystycznej oraz średniowiecznej. Z drugiej strony wiele jej twierdzeń jest nie do przyjęcia dla chrześcijan konserwatywnych, niezależnie od wyznań, oskarżających jej przedstawicieli właśnie o liberalizm ${ }^{1}$. Już ten bardzo lapidarny opis świadczy o kontrowersjach, jakie wśród teologów wzbudza ten kierunek. Do kontrowersji przyczyniają się również „autorskie” znaczenia przypisywane powszechnie znanym pojęciom, jak na przykład socjalizm, czy też niedostateczna, jak na szkołę deklarującą ortodoksję, uwaga przypisywana Kościołowi.

1 P. Hedges, Is John Milbank's Radical Orthodoxy a Form of Liberal Theology? A Rhetorical Counter, „The Heythrop Journal” 51 (2010), s. 795 (795-818). 
Szkoła RO podejmuje również temat krytyki kapitalizmu. Koronnym przykładem jest tutaj refleksja Johna Milbanka, lidera i twórcy tego środowiska teologicznego, autora, który wielokrotnie wypowiadał się na ten temat w licznych mniejszych formach, jak artykuły czy wywiady. Reprezentatywnym źródłem tej krytyki jest jego kluczowa publikacja zatytułowana Teologia $i$ teoria społeczna (Theology and Social Theory), od której zresztą rozpoczyna się pochód refleksji ruchu RO i samego Milbanka przez środowiska teologiczne i akademickie.

RO wpisuje się tym samym w pewną tendencję akademickiej teologii. Należy tu bowiem podkreślić, że krytyka kapitalizmu jest w ostatnich kilkunastu latach coraz częstszym polem zainteresowania teologów, zarówno katolickich, jak i protestanckich (w mniejszym stopniu również prawosławnych). Motyw ten jest także przedmiotem oficjalnego nauczania Kościołów i organizacji ponadwyznaniowych i ekumenicznych: wystarczy wspomnieć choćby encyklikę Franciszka Evangelii gaudium czy szereg deklaracji podejmowanych przez takie instytucje, jak Światowa Wspólnota Kościołów Reformowanych. O ile jednak w przypadku Kościołów refleksja ta jest raczej stricte teologiczna, odwołująca się do argumentacji biblijnej, patrystycznej i historycznoteologicznej, o tyle interpretacje indywidualnych teologów są interdyscyplinarne. Teologiczne są w nich punkt wyjścia i punkt odniesienia, które spinają klamrą wnioskowania posiłkujące się ekonomią, socjologią i filozofią.

Celem artykułu jest prezentacja fragmentu refleksji Johna Milbanka, odnoszącego się do krytycznej oceny kapitalizmu i ukazanie jej na tle podsumowania najważniejszych teologicznych punktów programowych szkoły RO, ze szczególnym uwzględnieniem wkładu samego Milbanka. Przedstawienie to ukazuje również charakterystyczne kierunki środowiska teologicznego skupionego wokół angielskiego myśliciela i sposoby konstruowania stanowisk wobec poszczególnych kwestii odnoszących się do współczesności. W artykule zostaje przeprowadzony analityczny komentarz wybranych tekstów Milbanka, tak zestawionych, aby w możliwie reprezentatywnym stopniu osiągnąć zamierzone cele. 


\section{JOHN MILBANK I RADYKALNA ORTODOKSJA: GŁÓWNE PUNKTY TEOLOGICZNE}

Głównymi przedstawicielami ruchu (choć zdaniem Paula Hedgesa RO właściwie nie jest ruchem, ale teologicznym środowiskiem) są anglikańscy teologowie: John Milbank, Catherine Pickstock i Graham Ward, pracujący na różnych brytyjskich uniwersytetach. RO jest jednak ex definitio środowiskiem ponadwyznaniowym i ekumenicznym, w którym uczestniczą również katolicy i protestanci różnych wyznań. Symbolicznym początkiem i jednocześnie manifestem RO jest zbiór esejów opublikowany w 1999 r. pod tytułem Radykalna ortodoksja: Nowa teologia (Radical Orthodoxy: A New Theology), jakkolwiek już wspomniana wcześniej książka Milbanka, wydana w 1990 r., powinna być traktowana właśnie jako moment inicjujący kierunek teologicznej refleksji RO.

Punktem wyjściowym w interpretacji poglądów Milbanka (i całej szkoły RO) może stać się stwierdzenie, że jest on zdecydowanym krytykiem nowoczesności i głębokim orędownikiem wydobycia teologii z kąta, do jakiego jest ona stawiana już właściwie od XIV wieku². To stwierdzenie dobitnie wyraża zresztą James Smith, jeden z członków ruchu, deklarujący, że „celem jest ponowne ustanowienie teologii królową nauk”.

Angielski teolog opiera swoje tezy na głębokiej analizie kierunków w historii teologii, filozofii oraz nauk społecznych, starając się objąć możliwie szeroką reprezentację poglądów i stwierdzeń dotyczących pojęć podstawowych. W pewnym sensie przenosi do dzisiejszej dyskusji średniowieczny spór o uniwersalia. Warto przytoczyć tu charakterystykę RO sformułowaną przez Roberta Woźniaka, który przyjmuje, że „tym, co łączy wspomnianych autorów, jest powrót do myślenia z głębi tradycji i pojęć tradycyjnie chrześcijańskich. Pojęcia te stają się instrumentarium wchodzenia w twórczy i niepozorowany dialog ze współczesnością. Milbank, Ward i Pickstock przypominają, że prawdziwy dialog ze współcze-

2 A. Ivorra, La "liturgia” de la Radical Orthodoxy. Entre Catherine Pickstock y James K. A. Smith, „Scripta Theologica” 43 (2011), s. 163-178.

${ }^{3}$ J.K.A. Smith, Introducing Radical Orthodoxy: Mapping a Postsecular Theology, Grand Rapids 2004, s. 167. 
snością nie tylko nie powinien porzucać starych pojęć chrześcijańskiego słownika, ale wręcz musi się do nich odwoływać"

Obserwacja współczesnej teologii oraz szerzej, współczesnego człowieka, społeczeństwa i kultury, prowadzi Milbanka do wysunięcia zdecydowanego postulatu rehabilitacji znaczenia prawd metafizycznych w życiu chrześcijanina, przesuwanych gdzieś w tył za fałszywą pobożność i fałszywą dobroczynność. Można bowiem odkryć, że kryzys chrześcijaństwa jest również (poza wieloma innymi czynnikami) wynikiem powszechnego przekonania, że życie ludzkie przebiega w ciemnej próżni jako jakiś przypadkowy punkt i że stworzenie jest akcydentalnym rezultatem losowego i materialnego procesu ${ }^{5}$. Jednocześnie, skoro wieki spychania metafizyki w obszar pozanaukowy (wystarczy przypomnieć przejście semantyczne, jakie dokonało się od łacińskiego scientia do współczesnego angielskiego słowa science $)^{6}$ doprowadziły do odebrania jej poznawczej wiarygodności, należy, jak podkreśla Milbank, bardziej zatroszczyć się o teologiczną interpretację kosmologicznych, fizycznych i biologicznych aspektów filozofii, tym bardziej że wspomniana przypadkowość czyni przypadkowymi również prawa natury. Właśnie kategorie wywodzące się z tych dziedzin tworzą przecież dzisiaj epistemologiczne środowisko człowieka. Pokora współczesnej teologii i zadowolenie się aktualnym intelektualnym schowkiem albo też z drugiej strony kapitulacja teologów są ślepym zaułkiem i zaprzeczeniem nakazu misyjnego. Przeciwnie, Milbank wzywa do ataku apologetycznego, który nie będzie bał się zakwestionować współczesnego ładu epistemologicznego, współczesnego społecznego imaginarium, odwołując się do terminu Charlesa Taylora i który będzie odważnym przypominaniem istoty teologii chrześcijańskiej. Zauważa, że nauka i filozofia, jeśliby uwzględnić zakładaną anarchiczną losowość, są zmuszone dzisiaj do stwierdzania nieskończoności możliwych światów, dla których jednak nie znajdują cienia empirycznych dowodów. Wyłania się

4 R. Woźniak, Radykalna Ortodoksja: próba definicji, „Znak” 7-8 (2010) nr 662-663, s. 10-20.

5 J. Milbank, Radical orthodoxy and Protestantism Today: John Milbank in Conversation, „Acta Teologica” 37 (2017), s. 43-72.

${ }^{6}$ Można tu przypomnieć o określeniu scientia fidei sformułowanym przez Leona Wielkiego. Zob. J. Szymik, Teologia jako nauka wiary, czyli scientia sui generis, „Śląskie Studia Historyczno-Teologiczne" 32 (1999), s. 96 (95-104). 
w ten sposób przestrzeń dla metafizycznego kącika, który zawiera w sobie obserwację, że regularność, jaką obserwujemy w kosmosie, opiera się na działaniach jakiejś immanentnej inteligencji. Przywołując tu Akwinatę, można zauważyć, że w tym przekonaniu o regularności rzeczywistości jest sensus communis, zdrowy rozsądek, rozumiany jako jakiś zmysł wewnętrzny, który jest „wspólnym korzeniem i wspólną zasadą zmysłów wewnętrznych"7. Jak zauważa Milbank, przyjmując kategorie biblijne, jest to „immanentne dzieło stworzonej Sofii, która paradoksalnie jest identyczna $\mathrm{z}$ transcendentną i "personifikującą« (jak to wyrażał Bułgakow) istotą Trójjedynego Boga"8.

Misja chrześcijan obejmuje również ukazywanie światu objawionego, teologicznego (a więc z perspektywy chrześcijan - prawdziwego) obrazu rzeczywistości. Przypadkowość i nieprzejrzystość świata, którą przedstawia współczesna nauka i dekonstruktywna filozofia, stawiają człowieka w fałszywym środowisku epistemologicznym. To zdaje się twierdzić Milbank, wchodząc w bardziej szczegółowy wywód antropologiczny. Podkreśla, że jeżeli przyjmujemy ciało i duszę za rzeczywistości nieredukowalne, teologia nie może pozostawiać ludzi z przekonaniem, że jako byty stworzone są wywodzeni „horyzontalnie”, a więc, że ich istnienie jest sprawą przypadkowych sił natury. Pierwszym zadaniem teologicznej epistemologii jest wykazywanie, że z jednej strony dusza i intelekt „wyłaniają się”, z drugiej zaś jednak przez to „horyzontalnie” działa „wertykalnie”, że to intelekt jest pierwszą stworzoną rzeczą, dając dalej początek duszy i materialnemu światu (odwołując się do Augustyna, Tomasza i wielu innych Ojców Kościoła). W konsekwencji, ta pierwotna teza epistemologiczna ma całkowicie fundamentalne znaczenie psychologiczno-duchowe, prowadzi bowiem do świadomego przyznania przez istotę stworzoną, że stworzenie jest darem. Poznajemy więc siebie, w akcie refleksji, jako dar, jednocześnie dla siebie i z siebie?.

Te podstawowe stwierdzenia teologicznoantropologiczne powinny więc być stale przypominane współczesnemu odbiorcy, który, co wszak podkreślają właściwie wszyscy teoretycy ponowoczesności, ciągle, ale bez-

\footnotetext{
7 H. Arendt, Myślenie, Warszawa 1991, s. 91.

8 J. Milbank, Radical Orthodoxy and Protestantism Today, s. 63.

9 Tamże, s. 65.
} 
skutecznie poszukuje sensu. Podobnie, w reakcji na „płynność” nowoczesności (liquid modernity), uciekając się do określeń Baumana, remedium jest hierarchiczny porządek kosmogoniczny w chrześcijaństwie, odbijający fundamentalną prawdę wiary dla chrześcijaństwa, jaką jest dogmat trynitarny. Jak podkreśla Milbank, przypominając Doktora Anielskiego, całość stworzonej rzeczywistości odzwierciedla Trójcę Świętą w systemie wychodzących relacji: od przyczyny mechanicznej, poprzez sianie, akty zwierzęce, aż po intelekt ludzki, który wymaga tak wewnętrznej, jak i zewnętrznej wypowiedzi „słowa”, powiązanego z duchowym pragnieniem realizacji celu. W ten sposób stworzenia wciąż powracają do siebie i w konsekwencji do Boga. Bóg jednak, jak przypomina angielski teolog, jest sam w sobie doskonałym samo-powracaniem, nie przez jakąś alienację czy odbicie, ale przez wydanie Potomka/Słowa, który jest Jego odzwierciedleniem o tyle tylko, o ile daje mu początek. To samo-powracanie odbywa się przez miłość ducha w akcie doskonałego obiegu. Zarazem akt ten jest prosty, ponieważ wzajemna miłość Ojca i Syna wylewa się, jako że jest to miłość prawdziwa; jest to również miłość „Zwrotna” wylewającego się Ducha do Ojca i Syna; a pośrednictwo (przez Syna), chociaż umożliwia tą zwrotną cyrkulację, jest ciągle „pośrednictwem mediacyjnym”, pośrednictwem zbieżnym z Boską istotą ${ }^{10}$.

Ten pierwotny porządek opierający się na uczestnictwie stworzenia we wspólnocie Trójcy Świętej zostaje przerwany przez grzech pierworodny i „niemożliwe” zatrzymanie trynitarnej cyrkulacji, ale odzyskany przez odkupienie, dokonane przez Stwórcę. Milbank ponownie przypomina tu św. Tomasza z Akwinu i jego uwagę, że przywrócenie pierwotnego porządku było możliwe jedynie dzięki działaniu tego, kto ten porządek stworzył. Zostaje on ponownie ustanowiony przez akt Inkarnacji i jej przedłużenie w działaniu Ducha Świętego w Kościele ${ }^{11}$. Angielski teolog, odnosząc się do przedstawionego powyżej schematu potwierdza kluczowe dla myślenia teologicznego przekonanie, że w ten sposób łączą się metafizyczny $z$ historycznym aspektem teologii.

Obie te teologiczno-filozoficzne ścieżki wnioskowania, a więc ta o stworzeniu jako darze i ta o istocie i porządku relacji odzwierciedlonym

\footnotetext{
10 Tamże, s. 68.

11 Tamże, s. 70.
} 
w Trójcy Świętej, właściwie ustawiają epistemologiczny punkt wyjścia. Dokonując przeglądu historii teologii w kontekście kształtowanym przez współczesność oraz współczesne konieczności i możliwości człowieka, Milbank jednoznacznie ogłasza, że należy dążyć do radykalizacji ortodoksji teologicznej, a nie jej liberalizacji. Wskazuje również, że szczegółowo ta radykalizacja mogłaby się dokonywać po linii tworzonej przez myślenie Orygenesa, Jana Szkota Eriugeny, Mistrza Eckharta oraz Mikołaja z Kuzy. Jakby - komentując ten postulat - przywołuje interpretację nauczania Orygenesa dokonaną przez Catherine Pickstock, towarzyszkę z grupy Radykalnej Ortodoksji, która wykazuje, że teolog z Aleksandrii był najważniejszym chrześcijańskim teologiem duchowości, alegorycznej egzegezy i wyznaniowej ortodoksji (credal orthodoxy) ${ }^{12}$, ale też która zauważa, że jego ortodoksja przynależała do nieco innego kontekstu metafizycznego niż późniejsza myśl teologiczna. Jak stwierdza Pickstock, Orygenes respektował różnicę pomiędzy czasem i wiecznością, między innymi poprzez ujmowanie ludzi (a nie tylko dusze) w ich pre- i postegzystencji, albo przez ujmowanie potępienia jako rzeczywistości „przedostatecznej”, jeżeli Bóg jest jednocześnie dobry i wszechmocny.

Z nauczania Orygenesa czy Eriugeny o kolektywym ujmowaniu zbawienia Milbank wywodzi również znaczenie i rolę Kościoła. Pośrednio można dostrzec w tym wnioskowaniu również socjologiczne przekonanie o współzależności jednostek oraz ich działań, co przekłada się na teologiczne stwierdzenie, że tak, jak zepsucie kogoś oznacza nieuniknione zepsucie innych, tak też nigdy nie zbawiamy się sami. Zbawienie wszystkich jest drogą utwierdzenia boskiej chwały. Pasterz, jak stwierdza Milbank, troszczy się przede wszystkim o jedną zgubioną owcę, ponieważ z powodu tej straty On sam gubi się i krąży. Ale skoro On nie może się gubić i krążyć, owca jest od zawsze i na zawsze, w perspektywie eschatycznej, znajdywana ${ }^{13}$.

12 Pojęcie wyznaniowej ortodoksji (credal orthodoxy) jest stosowane w teologii anglikańskiej, zwłaszcza w Stanach Zjednoczonych, mające wykazywać, że Kościoły anglikańskie (przede wszystkim Kościół episkopalny) zachowują wierność tradycji teologicznej określanej przez starożytne wyznania Kościoła powszechnego. Pojęcie to jest jednak przedmiotem krytyki zwłaszcza ze strony katolickiej, która zasadza się na wykazywaniu, że wierność ta jest fragmentaryczna, nieobejmująca nauczania moralnego.

${ }^{13}$ J. Milbank, Radical Orthodoxy and Protestantism Today, s. 72. 
Taka eschatologiczna perspektywa implikuje również przekonanie, że teologia nie doszła w żadnej mierze do „pełni ortodoksji” (i właściwie należałoby tu dodać, że nigdy nie dojdzie do takiej pełni) oraz, że część przypuszczalnie „heretyckich” stwierdzeń jest takimi z powodu niedostatecznej refleksji metafizycznej. Na tym stwierdzeniu (między innymi) zasadza się również podkreślana przez całą szkołę RO konieczność rozwijania metafizyki. Jest to postulat mający ogromne znaczenie nie tylko dla czysto akademickiej dyskusji, lecz także dla Kościoła i całego chrześcijaństwa. Należy bowiem mieć na uwadze pytanie Charlesa Taylora, do którego odwołuje się Milbank, ale i wielu innych, że odrzucanie przez społeczeństwa zachodnie chrześcijaństwa jest również powiązane $\mathrm{z}$ odrzuceniem lęku przez piekłem, jak i niechęcią do nadmiernej moralizacji Kościoła, a także, że chrześcijaństwo współczesne jest jednak inne w 2000 r. $\mathrm{w}$ porównaniu do np. $1500 \mathrm{r}^{14}$. Takie myślenie o sprawach religijnych i teologicznych również jest zbieżne z licznymi pozycjami z zakresu etyki opisowej i psychologii społecznej. Współcześnie bowiem zakres regulacji prawem (należy dodać stanowionym) oraz normami społecznymi, nawet jeżeli nie są sankcjonowane prawnie jest tak dalece sięgający, że ludzie uznają strach przed piekłem za zbyteczny. To zresztą jest pochodną procesu oświeceniowego „dorastania” świata, który przynosił również próby świeckiego zbawienia, skutkujące, jak stwierdza angielski teolog, „piekłem na ziemi”. Można powiedzieć, że Milbank odwraca teologiczne paradygmaty kształtowane kilkadziesiąt lat wcześniej przez Dietricha Bonhoeffera i wielu innych, tworzące na kilka dekad teologiczny mainstream na Zachodzie. Niemiecki teolog przyznawał, że metafizyczne poznanie Boga musi ustąpić przed oświeceniowym procesem zamykania luk w poznawaniu świata. Bóg jako pojęcie nie może być już „zapychaczem dziur” (Lückenbüßer) ludzkiego poznania ${ }^{15}$, a drogą chrześcijaństwa jest trwanie w elitarnych grupach nakierowanych na moralny radykalizm. Milbank przeciwnie, widzi dla teologii drogę wykorzystania poznawczego zamieszania w naukach przyrodniczych i filozofii, który współczesnego

${ }^{14}$ Ch. Taylor, A Secular Age, Cambridge 2007, s. 13.

15 D. Bonhoeffer, Widerstand und Ergebung. Briefe und Aufzeichnungen aus der Haft, Ch. Kaiser Verlag, München 1955, s. 210. 
człowieka czyni bezbronnym wobec pytań egzystencjalnych, mniejszą uwagę przywiązując do sfery moralnej.

\section{OCENA MARKSISTOWSKIEJ KRYTYKI KAPITALIZMU}

Jak zaznaczono na wstępie, szkoła RO ostro krytykuje nowoczesność. Milbank i inni teologowie RO sprawiają za to wrażenie przekonanych, że okres ponowoczesny niesie ze sobą szanse zmiany epistemologicznej (co trochę przypomina Thomasa Kuhna „zmianę paradygmatyczną” (paradigm shift) w perspektywie teologicznej ${ }^{16}$ ) i że teologia musi aktywnie uczestniczyć w tym przejściu, pokazując porządek oparty na teologicznej ortodoksji chrześcijaństwa. Częścią tego działania jest wskazywanie na szczegółowe symptomy (i jednocześnie elementy) nowoczesności, które sprzeciwiają się jej porządkowi, z sekularyzmem na czele. Należy do nich również kapitalizm.

Zwięzła prezentacja głównych kierunków szkoły RO i teologii samego Milbanka pozwala lepiej zrozumieć jego krytykę kapitalizmu. Angielski teolog rozwija swoją interpretację kapitalizmu pomiędzy Marksem, Weberem, Preudhonem i Ruskinem, odnosząc się zwłaszcza do tego pierwszego i wykorzystując najważniejsze punkty teorii marksistowskiej, aby wykazać, że teoria ta jest w swej krytyce nieadekwatna. W tle komentarza do marksistowskiej krytyki kapitalizmu przedstawia jego istotę i rozwija jego ocenę z punktu widzenia chrześcijańskiej wizji społeczeństwa.

Według Marksa kapitalizm, podobnie jak religia, jest na pewnym etapie historycznym konieczny. Poza tym, również podobnie jak religia, kapitalizm jest irracjonalny i skazany, aby w koniecznym procesie dziejowym upaść z powodu wewnętrznych sprzeczności. W tych stwierdzeniach, choć dobitnych, Milbank dostrzega istotne błędy. Pierwszy z nich, który angielski teolog wyjaśnia, odwołując się do wniosków Jean-François Lyotarda, polega na niedocenieniu wewnętrznego potencjału kapitalizmu do przystosowywania się do różnych warunków. Kapitalizm, ze swym formalizmem, zdolnością do definiowania jako „jednorodne” różnorodnych

${ }^{16}$ J.H. Olthuis, On Worldviews, w: P. Marshall, S. Griffioen, R.J. Mouw (red.), Stained Glass: Worldviews and Social Science, Lanham 1983, s. $27 \mathrm{n}$. 
pragnień ludzkich (można byłoby tu dodać jeszcze - wzbudzania tych pragnień), prac oraz towarów, sam czyni się wewnętrznie „tautologiczny”, w takim sensie, że jest zdolny do pozostania sobą w najróżniejszych sytuacjach i że może zawsze precyzyjnie określić zagrożenia i automatycznie sformułować adekwatną odpowiedź ${ }^{17}$. Oczywiście, krytyka kapitalizmu słusznie wskazuje na wewnętrzne napięcia w nim samym; Milbank przywołuje tutaj jako przykład konflikt pomiędzy potrzebą redukowania kosztów pracy a potrzebą stymulowania chęci posiadania danego towaru, ale dodaje również, że w teorii ekonomicznej można wskazać na nieskończenie wiele możliwości adaptacji kapitalizmu jako systemu, dziękim którym wieszczony przez Marksa jego ostateczny upadek jest nieprzerwalnie przesuwany w czasie. Kapitalizm będzie mieć swój potencjał tak długo, jak długo jest podtrzymywana asymetria pomiędzy bogactwem i władzą, a klasa przegrana może być albo zmuszana, albo zwodzona, aby pozostawać w stanie bezruchu ${ }^{18}$.

Drugi błąd Marksa dotyczy irracjonalności kapitalizmu. Można byłoby bowiem rzeczywiście, pozostając w obrębie tej myśli, myśleć jako o irracjonalnej o sytuacji, w której klasa podporządkowana zgadza się na swoje położenie. Milbank przeprowadza również tutaj głęboką analizę. Otóż punktem wyjścia powinno być przypomnienie, że marksizm jest zaliczany do tradycji spoglądającej na społeczeństwo jako na pole konfliktu, w odróżnieniu od strukturalizmu, który ujmuje je organicystycznie. Choć angielski teolog nie wspomina o Ralfie Dahrendorfie, który skutecznie połączył obie wizje, to jednak idzie domyślnie tym tropem, przywołując opinię samego Marksa o możliwości funkcjonalnego wykorzystania wewnętrznego konfliktu ${ }^{19}$. Poza tym przypomina, że autor Kapitału uważał zasadę konfliktu za organizującą życie społeczne w długiej perspektywie dialektycznego procesu historycznego i nie przewidywał granic takiej funkcjonalizacji.

Taki funkcjonalizm decyduje jednak o tym, co zdaje się twierdzić Milbank, że kapitalizmu nie można określić jako irracjonalny. Chociaż

\footnotetext{
17 J. Milbank, Theology and Social Theory: Beyond Secular Reason, Oxford 2006, s. 9.

18 Tamże, s. 192.

19 R. Dahrendorf, Klasy i konflikt klasowy w społeczeństwie przemysłowym,
} Kraków 2012, s. 41. 
w okolicznościach aktualnych dla samego Marksa, mógł on pisać o obiektywnym konflikcie interesów kapitału i pracowników, to jednak błąd mógł polegać na pełnym utożsamieniu istoty ludzkiej z robotnikiem, tak, jakby nie był on jednocześnie konsumentem albo po prostu kimś zwiedzonym obietnicami kapitalizmu. Można tu dodać, że ta rola człowieka pełniej odsłoniła się w trakcie rozwoju kapitalizmu, co podkreśla dzisiaj krytyka społeczeństwa konsumpcyjnego, posiadającą przecież również, a może przede wszystkim, swą marksistowską wariację ${ }^{20}$. Jak zauważa Milbank, większość ludzi może przyjmować fikcję, w której inwestorzy-kapitał są nagradzani po prostu za zwodzenie ludzi. Inaczej mówiąc, miliony pracowników-konsumentów akceptują różne mechanizmy manipulacji podtrzymujących trwanie kapitalizmu, dlatego że zapewniają one istnienie społeczeństwa, które organizowane jest wokół celebrowania różnych form pustej jednoznaczności. Angielski teolog znowu zdaje się tutaj wchodzić w terminologię oraz kategorie charakterystyczne dla krytyki społeczeństwa konsumpcyjnego ${ }^{21}$. To samo wnioskowanie prowadzi go również do konkluzji, że nie można określić kapitalizmu jako irracjonalnego.

W krytyce społeczeństwa konsumpcyjnego kluczowe jest stwierdzenie, że rozwija ono własną logikę, która obejmuje wszystkich i wszystko pozostających $\mathrm{w}$ jej zasięgu i w ten sposób nadaje też sens dążeniom i pomysłom, które poza tą logiką jawią się jako niedorzeczne. Podobnie też kwestię marksistowskiego twierdzenia o irracjonalności kapitalizmu widzi Milbank. Jak stwierdza, przeciwstawianie się kapitalizmowi może zachodzić tylko wtedy, kiedy wyjdzie się poza wewnętrzną logikę kapitalizmu i inaczej niż on ujmuje się wartości, jak na przykład wolność.

Nie jest też adekwatnym sprowadzanie kapitalizmu do ideologii, zwłaszcza w marksistowskim rozumieniu, jako stwarzającej „fałszywą świadomość", a więc błędne rozumienie funkcjonowania świata. Do tej powszechnie znanej definicji Milbank dodaje stwierdzenie, że Marksa ujęcie ideologii zakłada dystans pomiędzy rzeczywistymi siłami społecznymi a ich ideową reprezentacją. Tymczasem zdaniem angielskiego teologa jest raczej tak, że pewne ideologiczne wyrazy kapitalizmu, wykorzystywane

20 J. Milbank, Theology and Social Theory, s. 195.

${ }^{21}$ C. Campbell, A Critique of Veblen's Theory of Conspicuous Consumption, „Sociological Theory” 13 (1) (1995), s. 38. 
niekiedy przez polityków (koronnym przykładem jest tutaj iluzja „równych szans dla wszystkich"), służą raczej do ukrywania innych możliwości porządku społecznego, ale nie maskują samej ich istoty. Innymi słowy, chociaż teoretycy kapitalizmu mogą, nawet dość powszechnie, stosować pewne ideologiczne „kamuflaże”, to nie jest to inhreretna i konieczna cecha samego kapitalizmu ${ }^{22}$.

Natomiast taką inherentną cechą samego kapitalizmu jest to, że jest to system, który ujmuje dowolność, albo też różnorodność, jako istotę samego siebie. Kapitalizm tworzy więc pewną „świecką” logikę, która nie przyjmuje żadnych faktycznych (substantive) norm i która ma potencjał, aby absorbować i przezwyciężać w obrębie własnych zasad każdy tradycyjny system wymiany kulturowej. Powyższe uwagi prowadzą Milbanka do stwierdzenia, że kapitalizmu nie można przedstawiać jako systemu irracjonalnego.

Angielski teolog zwraca uwagę na jeszcze jedną kwestię, która charakteryzuje współczesny kapitalizm i która czerpie z teorii marksistowskiej. W Zarysie krytyki ekonomii politycznej Marks dostrzegał, że kapitalizm absorbujący postęp technologiczny i automatyzację będzie prowadził od przywłaszczania indywidualnej pracy do przywłaszczania ogólnego potencjału produkcyjnego ludzkości, jej rozumienia natury oraz jej panowania nad naturą. Jak zauważa angielski teolog, ale i jak widzi to wielu komentatorów Marksa, zachodzi tutaj pewien paradoks; w teorii marksistowskiej zakłada się zdemaskowanie zwrotu ludzkiego potencjału przeciwko samej ludzkości, jako że coraz powszechniejsza edukacja będzie prowadziła do wykazania, że korzyści niewielkiej grupy są nadrzędnie wobec korzyści większości ludzi. Zdaniem Milbanka, to jednak, co dzisiaj obserwujemy, to jest kapitalizm „zdezorganizowany”, w którym takie jego elementy jak konkurencja, nowe zawody i nowe sposoby wykorzystania wartości dodatkowej (surplus value) reprodukują się w różnych podsystemach w obrębie monopoli ${ }^{23}$. Można byłoby dodać, że gwałtowny postęp technologiczny, w którym maszyny nieodwracalnie zastępują człowieka, pozbawia znaczenia napięcie pomiędzy pracą a kapitałem i sprowadza większość ludzi do pozycji konsumenta, jeszcze bardziej zależnego od kapitału niż sto lat wcześniej. Poza tym, na co

22 J. Milbank, Theology and Social Theory, s. 194.

23 Tamże, s. 195. 
zwraca też uwagę Milbank, współczesna edukacja, skoncentrowana na umiejętnościach technologicznych, nie oznacza wyższego poziomu edukacji ogólnej, co pozbawia większość ludzi kompetencji do rozpoznania faktycznego położenia. Angielski teolog sygnalizuje tutaj zjawisko, które w kolejnych latach stanie się przedmiotem rosnącej troski znacznej części obserwatorów życia społecznego ${ }^{24}$.

Wykazanie, że - stosując teorię marksistowską - nie jest możliwe ujmowanie kapitalizmu jako irracjonalnego, prowadzi Milbanka do wniosku, iż jedynie etyczna i religijnie ugruntowana krytyka kapitalizmu jest efektywna. Na uzasadnienie takiego stwierdzenia teolog podaje dwie racje. Po pierwsze przypomina, że dla Marksa (a trzeba też dodać dla całej rzeszy następców autora Kapitału, z najbardziej znanym promotorem tego skojarzenia,Walterem Benjaminem) kapitalizm jest jakąś formą religii, skoro obejmuje kulturowo cały system znaczeń. Dlatego też, jak stwierdza Milbank, może być kwestionowany tylko z pozycji innej religii. Po drugie, co też zdaje się być istotniejsze, taka „religijność” kapitalizmu jest sama w sobie paradoksem, skoro jest on zawarty w logice całkowicie świeckiej przestrzeni. Jest to więc religijność zwodząca, kierująca na obiekt, który w swej naturze jest całkowicie świecki (angielski teolog określa to jako „paradoksalną religijność samego świeckiego”). Wychodząc od podstawowych obserwacji, jest oczywiste, że kapitalizm, ze swą formalną i kalkulatywną logiką zysku i konkurencji, może być odpierany jedynie przez konstytutywną logikę systemu, u którego podstaw jest metafizyka i który promuje pewne role społeczne jako obiektywnie pożądane w obrębie pewnej narracji społecznej ${ }^{25}$. Zatem jest to logika, która nadaje rolom społecznym sens wynikający z porządku zewnętrznego wobec samego systemu ${ }^{26}$.

\section{SZANSE CHRZEŚCIJAŃSKIEGO SOCJALIZMU}

Nie oznacza to jednak, że alternatywna dla kapitalizmu musi być koncepcja organicystyczna i hierarchiczna społeczeństwa. Milbank zdaje

${ }^{24}$ Lifelong Learning. How to Survive in the Age of Automation, „The Economist” 14 January 2017, s. 11.

25 J. Milbank, Theology and Social Theory, s. 197.

26 Tamże, s. 198. 
się koncentrować na znaczeniu cnoty jako organizującej życie społeczne, a nie na jego strukturze. Dlatego też może stwierdzić, że społeczeństwo dążące do doskonałości (co wyraża pojęciem paideia), a więc do pewnych wartości, może być jednocześnie społeczeństwem nakierowanym na równość społeczną i ekonomiczną oraz na republikańskie uczestnictwo w procesie politycznym. Jak stwierdza, paradoksalnie większość XIX-wiecznych propozycji socjalistycznych było taką kombinacją „konserwatywnej” drogi paidei, powszechnie przyjmowanych wartości oraz religijności z nowoczesnym rzecznictwem równości, braterstwa i wolności. Takie socjalistyczne propozycje stały w sprzeczności z marksistowskim, nowoczesnym wariantem socjalizmu, opierającym się na paradygmacie oświeceniowym i zakładającym w ostateczności czysto utylitarny model społecznej współpracy podporządkowany wartości pełnej realizacji jednostkowej wolności ${ }^{27}$.

Realizacje nowoczesnych wersji socjalizmu wykazały, że są one mniej spójne z jednej strony i mniej elastyczne z drugiej niż model rynkowy, który, jak pisze Milbank, niejako automatycznie rejestruje szanse i zagrożenia dla powiększania bogactwa danego społeczeństwa. Mechanizm rynkowy umożliwia porządek społeczny, w którym zasadą publicznie uznaną jest „wolność wyboru”. W nowoczesnych, i trzeba dodać, jeszcze do niedawna dominujących modelach liberalnego socjalizmu, zakłada się mechanizmy, które wprowadzają korekty w pewne niesprawiedliwości wynikające z zestawiania zysków i stat w postaci zasad państwa dobrobytu oraz systemów edukacji (przekazywanych również kolejnym pokoleniom; idea, którą dobrze obrazuje pojęcie zrównoważenia, sustainability, tak ważna dla globalnej polityki społecznej w ostatnich dwóch dekadach). Jednak, przyjmując szerszą perspektywę, tenże mechanizm rynkowy nie wystarcza do tego, by uniknąć zagrożenia istnienia władzy sprawowanej dla samej władzy. W sytuacji, w której decyzje jednych rzutują na życie innych, musi istnieć jakaś społeczna umowa o celu, do którego dąży dana społeczność. Milbank ilustruje to przykładem modeli edukacyjnych; w decyzji o tym, czego i jak się naucza, dane społeczeństwo wyraża swoją wizję tego, czym jest samospełnienie, nawet jeżeli nie jakieś cele zewnętrzne, jak sprawiedliwość i pokój, ale właśnie takie samospełnienie jest jedynym

27 Tamże, s. 199. 
celem. Jednak w takim modelu to właśnie władza jest celem samym W sobie ${ }^{28}$.

W przeciwieństwie do nowoczesnych, postoświeceniowych wersji socjalizmu, XIX-wieczne romantyczne wersje nie ujmowały socjalizmu jako kolejnego, stopniowego i dialektycznego procesu emancypacji, a ich krytyka kapitalizmu koncentruje się na perspektywie etycznej. Milbank przywołuje tutaj przykład Johna Ruskina, filozofa, filantropa i jednego z najwybitniejszych krytyków sztuki XIX wieku. Jego ujęcie wydaje się adekwatne w ukazywaniu podejścia, które teolog definiuje jako chrześcijański socjalizm, choć, jak zaznacza, Ruskin nie określał się ani jako socjalista par excellance, ani jako ortodoksyjny chrześcijanin.

Swoje poglądy Ruskin przedstawił w zbiorze esejów dotyczących ekonomii politycznej zatytułowanym Unto this Last. Sednem jest tutaj stwierdzenie, że kapitalizm jawi się jako apostazja, jako naoczny przykład systematycznego nieposłuszeństwa narodu wobec zasad własnej religii. Jest jakimś przypadkowym pseudo-postępem, praktykowaniem fałszywej wiedzy, której celem z jednej strony był interes własny dla samego interesu bez jakiegokolwiek ograniczenia wartościami, z drugiej zaś zabezpieczenie porządku publicznego nieopierającego się jednak na sprawiedliwości. Triumf zawierającej się w kapitalizmie ekonomii politycznej pociągał za sobą promocję pozornych wartości, jak „zajętość” czy oszczędność w miejsce prawdziwej phronesis i chrześcijańskiej charytatywności. Zaś po tym, jak religia musiała ustąpić ze sfery publicznej, pustkę po niej zapełnił jakiś ekonomiczny reżim organizujący społeczeństwo, nawet bez konsensusu ekonomicznego czy też religijnego ${ }^{29}$. Charakterystyczne jest, że diagnozy Ruskina wciąż brzmią aktualnie, kiedy obserwowuje się życie codzienne społeczeństw zachodnich.

Milbank zauważa również, że Ruskin, jakby wbrew oskarżeniom Marksa, że ten dziewiętnastowieczny socjalizm nie zwraca uwagi na historię, dostrzega fundamentalną zmianę historyczną, jaką przyniósł ze sobą kapitalizm. Mianowicie, całkowicie zmienił on logikę ludzkiego działania, w której zasady moralne zostały zastąpione amoralnymi, albo, mówiąc inaczej, „rachunek sprawiedliwości ustąpił przed „rachunkiem własnych

28 Tamże, s. 201.

29 Tamże, s. 200. 
korzyści”. Wiedza, którą zawiera ekonomia polityczna, jest jedynie jakimś ekstraktem systemu wiedzy, z której składa się sam kapitalizm. Jest to jednak pierwszy w historii przykład „nie-wiedzy” (nescience), dlatego że nie tyle rozwija ona maksymalną doskonałość w swoim kierunku, ile usprawiedliwia intencjonalne wykorzystywanie różnic w kompetencjach i zdolnościach. Relatywne nieudacznictwo, słabe umiejętności, złe rzemiosło oraz głupota dla kapitalizmu mają kluczową funkcję w redukcji kosztów. Ponadto, jak stwierdza za Ruskinem Milbank, ta specyficzna nie-wiedza przeprowadza ostry podział pomiędzy sferą naturalnych sympatii ugruntowanych w uniwersalnych odczuciach i sferą sztucznych sympatii wobec pozytywnych faktów własności, posiadania i władzy politycznej ${ }^{30}$. Nie-wiedza kapitalistyczna nie może więc tworzyć społeczeństwa opartego na cnocie, ale raczej zbiorowość ludzi kierującą się makiaweliczną skutecznością.

Pragnieniem Ruskinia jest łączenie bogactwa z prawdziwą cnotą. W wyrażaniu tej intencji ważne jest jednak pewne historyczno-kulturowe zastrzeżenie, które przypomina, że spora część zajęć traktowana była jako upośledzająca, niegodna, inaczej mówiąc, uprawiane zajęcie zbiegało się z zajmowaną pozycją społeczną (warto tutaj odnieść się do wybitnego rozróżnienia, jakiego dokonała Hannah Arendt w Kondycji ludzkiej, dzieląc ludzkie aktywności, vita activa, na działanie, wytwarzanie i pracę) ${ }^{31}$. Jak pisał angielski filozof, handel i rzemiosło nie były nigdy ujmowane jako obciążone jakąś wewnętrzną odpowiedzialnością, jakimś rodzajem poświęcenia, które przypisywane było nauczycielom, lekarzom czy też żołnierzom. W konsekwencji, w klasycznym ujęciu, choć działanie ekonomiczne podporządkowane było wartościom politycznym, to jednak sama produkcja nie była kojarzona $\mathrm{z}$ cnotą. Ponadto, takie podejście włączało w obszar cnoty politycznej funkcje $\mathrm{z}$ reguły zarezerwowane dla wolnych mężczyzn.

Milbank zauważa, że przeciwieństwem tego były tendencje wyrastające z chrześcijaństwa, w których dokonywało się łączenie koncepcji polis i oikos. Ich sednem było czynienie podstawową jednostką ekonomiczno-polityczną gospodarstwa domowego (household, Haushalt), z jego

\footnotetext{
30 Tamże.

31 H. Arendt, Kondycja ludzka, Warszawa 2010, s. 130.
} 
pastoralnym (chrześcijańskim) nadzorem nad dobrostanem materialnym. W takim porządku również kobiety, dzieci i niewolnicy, dotąd wykluczeni, stawali się pełnymi członkami wspólnoty religijno-politycznej. Ten inkluzywny model gospodarki i relacji społecznych prowadził do odkrywania również w produkcji i wymianie (handlu) ich immanentych norm cnoty i paidei ${ }^{32}$. Warto tu przypomnieć, że Ruskin był jednym z krytycznych recenzentów epoki wiktoriańskiej z jej ustalonymi strukturami społeczeństwa. W dwóch esejach zebranych pod tytułem Sesame and Lilies opisał porządek współczesnej sobie Angli opierający się na wyraźnym podziale pomiędzy sferą prywatną czy też domową, będącą domeną kobiet, a sferą publiczną, obejmującą handel, rządy i zajęcia eksperckie, wymagającą agresji, aktywności i intelektu, będącą domeną mężczyzn ${ }^{33}$.

Kolejną kwestią była zależność pomiędzy estetyczną jakością przedmiotów produkowanych badź wymienianych a ich etycznymi celami dla podmiotu społecznego. Sprawiedliwa wymiana dóbr i pracy zakłada związek pomiędzy etycznym „potencjałem” osób i interpretowaną doskonałością przedmiotów materialnych. W konsekwecji producentom i kupcom powinno zależeć na wysokiej jakości produktów nie tylko ze względu na prawa wolnego rynku, ale po prostu poprzez objęcie aktywności gospodarczej normami etycznymi. Jak podsumowuje Milbank, Ruskin dążył do zniesienia „sfery ekonomicznej” jako rzeczywistości indyferentnej wobec obiektywnego dobra, piękna i prawdy ${ }^{34}$. Demaskował kapitalizm jako logiczne zabijanie doskonałości i przekonania, że przez sztukę i praktykę jest się w stanie odkryć właściwy cel rzeczy (tymi poglądami Ruskina inspirowali się prerafaelici). Myśl angielskiego filozofa pomaga uzasadniać przekonanie, że faktyczna krytyka kapitalizmu może być prowadzona jedynie poprzez odwołanie się do transcendencji. Jednocześnie Ruskin ukazywał, że etyczne ujmowanie produkcji i handlu nie stoi na przeszkodzie egalitaryzmowi, w takim sensie, że choć podkreśla znaczenie ról opiekuńczych i pastoralnych, a więc hierarchizację społeczeństwa, to jednak nie łączy ich z bogactwem i przywilejami. Jest to więc raczej

32 J. Milbank, Theology and Social Theory, s. 201.

${ }^{33}$ D. Cordea, Two approaches on the philosophy of separate spheres in midVictorian England: John Ruskin and John Stuart Mill, „Procedia - Social and Behavioral Sciences” 71 (2013), s. 117.

${ }^{34}$ J. Milbank, Theology and Social Theory, s. 202. 
hierarchia funkcji, a nie hierarchia pozycji. Sugeruje nawet, że istota tych ról będzie zabezpieczona, jeżeli będą one rozproszone i tak dalece, jak to jest możliwe, wzajemne w kształtowaniu jakiejś powszechnej warstwy inteligencji całego społeczeństwa ${ }^{35}$. Istnieją oczywiście obszary, gdzie taka wzajemność nie jest możliwa, jak na przykład w procesie edukacji, gdzie musi istnieć relacja hierarchiczna, to jednak sama edukacja powinna być rozważana jako przyczyniająca się do samoniwelowania tej hierarchiczności. Niemniej jednak dla Milbanka jest więc istotna obserwacja, że chrześcijański socjalizm przywiązany do zbiorowych norm sprawiedliwości, które muszą być przekazywane w czasie i między pokoleniami, musi również akceptować hierarchiczność.

Krytyczne prześwietlenie poglądów Marksa i Ruskina staje się dla Milbanka okazją do wyrażenia własnej wizji porządku ekonomiczno-społecznego. Zamykając niejako pętlę wywodu, należy powrócić do programowych punktów całej refleksji angielskiego teologa. W ocenie jego krytyki kapitalizmu kluczowe jest przypomnienie, że najważniejszym zadaniem teologii jest odzyskanie epistemologicznej dominacji, tak, aby poznanie ludzkie odbywało się w obrębie wiary w Trójjedynego Boga. Kapitalizm jest pochodną nowoczesności i, w konsekwencji, sekularyzmu, a więc jednocześnie musi być traktowany z teologiczno-epistemologicznego myślenia jako błędny. Teologia powinna więc szukać inspiracji w okresie, w którym nie wykształcił się jeszcze podział między świeckim i duchowym, w okresie przednowożytnym (jakkolwiek ustalenie, gdzie przebiega granica czasowa jest zadaniem wywołującym wiele polemik). Milbank w pierwszym akapicie do Teologii i teorii społecznej dobitnie stwierdza, że

kiedyś nie było przestrzeni „świeckiego”. I „świeckie” nie było ukryte, czekając na wypełnienie atmosfery oparami „czysto ludzkimi” kiedy tylko złagodniał nacisk „świętego”. Zamiast tego istniała jednak wspólnota chrześcijaństwa, z jego dwoma aspektami sacerdotum i regnum. Seculum, $\mathrm{w}$ średniowieczu, nie było przestrzenią, domeną, ale czasem, interwałem pomiędzy grzechem pierworodnym a eschatonem, w którym represyjna sprawiedliwość, prywatna własność i niedoskonały naturalny rozum mu-

35 Tamże, s. 200. 
siały się rozwijać, aby stawiać czoło nieodkupionym efektom grzesznego człowieczeństwa ${ }^{36}$.

Zestawienie analizy krytycznych ocen kapitalizmu z tym programowym twierdzeniem Milbanka czyni bardziej zrozumiałym jego sympatię dla tęsknot za zerwaną ciągłością ze średniowieczem, wyrażaną na przykład przez Ruskina. Uzmysławiają również bardziej, jak zbiega się obserwacja angielskiego teologa o rezultatach utraty epistemologicznej dominacji przez teologię z jego podkreślaniem, że kapitalizm tworzy własną logikę, która czyni go racjonalnym i spójnym, choć naturalnie tylko w swoim obrębie. Milbank podziela myśl wyrażaną np przez Waltera Benjamina, że kapitalizm jest jakby quasi-religią; z jego wywodem przywołującym Marksa z jednej strony i Ruskina z drugiej współbrzmi zresztą teza Benjamina o kapitalizmie jako systemie wymagającym ciągłej celebracji i wpędzającym człowieka w stałe poczucie winy wobec niemożności wypełniania jego nakazów ${ }^{37}$.

Takie metafory uzmysławiają, jak wielka epistemologiczna moc jest przypisywana kapitalizmowi przez jego krytyków. Można tu ustawić pewną koniunkcję: skoro świeckość oznacza działanie jakby Bóg nie istniał, a kapitalizm jest pochodną świeckiej nowoczesności, to w konsekwencji współczesna ekonomia wolnego rynku ułatwia i utwierdza styl życia „bez Boga”, dostarczając jednocześnie alternatywnego dla teologicznego kontekstu instytucjonalnego, w którym funkcjonuje nauka, technologia i większa część kultur. Ekonomia ta wspiera też wartości wolności i autonomii, ale trzeba tu dodać, znowu pojmowane w obrębie logiki kapitalizmu, jako nie wykraczające poza system oparty o porządek skuteczności i konkurencji. W konsekwencji w interpretacji Milbanka współczesna ekonomia i współcześni ekonomiści są aktywnie zaangażowani w rozprzestrzenianie praktycznego ateizmu ${ }^{38}$.

Dlatego też angielski teolog stanowczo stwierdza, że jedyna możliwa krytyka kapitalizmu może wyrastać z teologicznego, chrześcijańskiego

36 Tamże, s. 9.

${ }^{37}$ W. Benjamin, Kapitalismus als Religion, w: D. Baecker (red.), Kapitalismus als Religion, Berlin 2003, s. 15nn.

38 J. Lunn, Capitalism as Heresy: On Why Theologians Criticize Markets, „Faith and Economics" 57 (2011), s. 5. 
punktu wyjścia. I choć krytykuje nowoczesność, to jednak chce zachować nowoczesny raczej egalitaryzm, nie usuwając herarchii tam, gdzie jest ona konieczna. W konsekwencji opowiada się za porządkiem ekonomiczno-społecznym, który jest bliski chrześcijańskiemu socjalizmowi, uosobianemu przez Pierre’a Bucheza oraz przez opisanego powyżej Johna Ruskina. Jak zresztą stwierdza, to Ruskin był bliski „zrozumienia, że sprawiedliwa wymiana oraz prawdziwa równość są możliwe jedynie tam, gdzie istnieje permanentnie odnawiana zgoda co do norm i wartości kulturowych i żaden indywidualny mechanizm ekonomiczny nie może zastąpić tego kompleksowego wymogu"39.

Jak zaznaczono na wstępie, Milbank nadaje powszechnie przyjętym pojęciom własne znaczenia. To dotyczy również socjalizmu. Socjalizm wyobrażony przez Milbanka nie ma nic wspólnego z socjalizmem postmarksistowskim. Nie chodzi w nim o zastąpienie działania rynku przez centralne sterowanie gospodarką ${ }^{40}$. Raczej, „socjalizm ten musi odkryć sposoby, w jakich wymiany rynkowe są usankcjonowane demokratycznie i dobrowolnie zaaprobowanymi transakcjami - rezultatami procesów wolnych i równorzędnych negocjacji, które permanentnie poszukują sposobów zachowania bądź też rozszerzania sprawiedliwej dystrybucji zasobów" ${ }^{31}$. A więc jest to socjalizm, który nie może być indyferentny wobec dążeń do sprawiedliwości, który nie pozostawia przestrzeni ekonomicznej czysto rynkowym siłom podaży i popytu, który wyklucza wykorzystywanie dla zysku sytuacji niedostatku czy konieczności i który nie akceptuje uznania każdej wyrażonej potrzeby, ale też nie próbuje zatamować tych potrzeb, których rozpowszechnianie uznaje się za uzasadnione i korzystne ${ }^{42}$.

Przekonanie, że stworzenie i odkupienie jest darem danym całkowicie darmo, ma fundamentalne znaczenie dla myślenia o otaczającym nas świecie. W takiej perspektywie Milbank rozwija również refleksję o ekonomii daru. Chrześcijaństwo ma potencjał, aby zmieniać relacje ekonomiczne warunkowane obecnie kalkulatywnością poprzez ujmowa-

\footnotetext{
39 J. Milbank, Theology and Social Theory, s. 202.

${ }^{40}$ J. Lunn, Capitalism as Heresy, s. 8.

${ }^{41}$ J. Milbank, The World Made Strange, Oxford 1997, s. 271.

${ }^{42}$ J. Lunn, Capitalism as Heresy, s. 8.
} 
nie ich jako postępujący proces dawania i otrzymywania darów. Opisując ściślej ten model ekonomiczny, wykazuje, że ujmowanie jakiegoś produktu albo usługi jako daru (a nie tylko towaru, commodity) powodowałoby, że wewnętrzna współpraca syndykalistyczna (przy czym syndykalizm można tu rozumieć w znaczeniu, jakiego można doszukać się u Pierre-Josepha Proudhona) będzie sie łączyć z szerszą współpracą ekonomiczną. Wolny rynek $\mathrm{w}$ takim systemie istniałby, ponieważ, jak pisze Lunn, w wizji Milbanka istotą socjalizmu nie jest ograniczanie rynku, ale rekonstrukcja wymiany według protokołu uniwersalnej wymiany darów, oznacza to, że w każdej transakcji coś innego niż rachunek zysków i strat powinno być przedmiotem negocjacji ${ }^{43}$.

Jak już wspomniano, Milbank wpisuje się w szeroki nurt teologów krytykujących kapitalizm i postulujących radykalną zmianę stosunków politycznych, ekonomicznych i społecznych współczesnego świata. Jego krytyka ma jednak odmienny charakter, zwłaszcza, jeżeli zestawić ją z wypowiedziami przedstawicieli Kościołów i organizacji kościelnych. Milbank skrupulatnie bowiem sięga do refleksji filozoficznej i socjologicznej, starając się dociec natury kapitalizmu i wykazać leżące w nim błędy sui generis. Czytając dokumenty kościelne, ma się wrażenie, że koncentrują się one na przejawach kapitalizmu, zwłaszcza kryzysowych. Angielski teolog, poprzez metaocenę teorii marksistowskiej z jednej strony i przedstawiającej ujęcie chrześcijańskiego socjalizmu z drugiej, dostarcza w miarę spójnej charakterystyki pozycji kapitalizmu w rzeczywistości społecznej. Obserwacja epistemologicznej siły kapitalizmu przybliża go bardzo do całego szeregu teoretyków współczesnego społeczeństwa konsumpcyjnego, piszących zresztą z pozycji postmarksistowskich. Milbank, w odróżnieniu od nich proponuje jednak konkretne rozwiązanie, i to zarówno $\mathrm{w}$ perspektywie ogólnej, jak i w perspektywie szczegółowej. W tej pierwszej jest wyjście z wewnętrznej logiki kapitalizmu i powrót do logiki kształtowanej przez założenia chrześcijańskiej metafizyki. W drugiej to postulat odrzucenia wyłączności rachunku zysków i strat jako ekonomicznej normy i afirmacja zasady rozszerzania sprawiedliwości dystrybucji zasobów, a także promocja idei ekonomii daru.

43 Tamże. 
Oceniając to podejście, należy podkreślić, że jego wielką wartością jest dialog z naukami społecznymi. Milbank, mimo wielu kontrowersji, jakie wzbudza jego teoria, uczestniczy w interdyscyplinarnej debacie i stara się uczynić swe teologiczne podejście bardziej zrozumiałym dla odbiorcy, dla którego chrześcijańskie kategorie, jak i myślenie metafizyczne jest już niezrozumiałe. Pozostaje kwestią dyskusyjną, na ile jego szczegółowe propozycje mają potencjał realizacji. Niemniej jednak ich sygnalizowanie jest już ważnym wkładem w refleksję teologiczną dotyczącą współczesnego porządku ekonomicznego.

\section{BIBLIOGRAFIA}

Arendt H., Kondycja ludzka, Wydawnictwo Aletheia, Warszawa 2010.

Arendt H., Myślenie, Czytelnik, Warszawa 1991.

Benjamin W., Kapitalismus als Religion, w: D. Baecker (red.), Kapitalismus als Religion, Kulturverlag Kadmos, Berlin 2003.

Bonhoeffer D., Widerstand und Ergebung. Briefe und Aufzeichnungen aus der Haft, Ch. Kaiser Verlag, München 1955.

Campbell C., A Critique of Veblen's Theory of Conspicuous Consumption, „Sociological Theory" 13 (1)(1995).

Cordea D., Two approaches on the philosophy of separate spheres in midVictorian England: John Ruskin and John Stuart Mill, „Procedia - Social and Behavioral Sciences” 71 (2013), s. 115-122.

Dahrendorf R., Klasy i konflikt klasowy w społeczeństwie przemysłowym, Zakład Wydawniczy NOMOS, Kraków 2012.

Hedges P., Is John Milbank's Radical Orthodoxy a Form of Liberal Theology? A Rhetorical Counter, „The Heythrop Journal” 51 (2010), s. 795-818.

Ivorra A., La "liturgia” de la Radical Orthodoxy. Entre Catherine Pickstock y James K. A. Smith, „Scripta Theologica” 43 (2011), s. 163-178.

Lifelong Learning. How to Survive in the Age of Automation, „The Economist” 14 January 2017. Lunn J., Capitalism as Heresy: On Why Theologians Criticize Markets, „Faith and Economics" 57 (2011), s. 1-24.

Milbank J., Radical orthodoxy and Protestantism Today: John Milbank in Conversation, „Acta Teologica” 37 (2017), s. 43-72.

Milbank J., The World Made Strange, Blackwell Publishing, Oxford 1997.

Milbank J., Theology and Social Theory: Beyond Secular Reason, Blackwell Publishing, Oxford 2006.

Olthuis J.H., On Worldviews, w: P. Marshall, S. Griffioen, R.J. Mouw (red.), Stained Glass: Worldviews and Social Science, University Press of America, Lanham 1983. 
Smith J.K.A., Introducing Radical Orthodoxy: Mapping a Postsecular Theology, Baker Academic, Grand Rapids 2004.

Szymik J., Teologia jako nauka wiary, czyli scientia sui generis, „Śląskie Studia Historyczno-Teologiczne" 32 (1999), s. 95-104.

Taylor Ch., A Secular Age, The Belknap Press of Harvard University Press, Cambridge 2007.

Woźniak R., Radykalna Ortodoksja: próba definicji, „Znak” 7-8 (2010) nr 662-663, s. $10-20$. 